Canadian Journal of Fisheries and Aquatic Sciences

Canadian

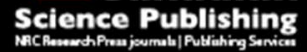
Journal canadien des sciences halieutiques et aquatiques

\title{
Corresponding long-term shifts in stream temperature and invasive fish migration
}

\begin{tabular}{|r|l|}
\hline Journal: & Canadian Journal of Fisheries and Aquatic Sciences \\
\hline Manuscript ID & cjfas-2017-0195.R1 \\
\hline Manuscript Type: & Article \\
\hline Date Submitted by the Author: & 20 -Jul-2017 \\
\hline Complete List of Authors: & $\begin{array}{l}\text { McCann, Erin; Central Michigan University, Institute for Great Lakes } \\
\text { Research } \\
\text { Johnson, Nicholas; USGS, Great Lakes Science Center, Hammond Bay } \\
\text { Biological Station } \\
\text { Pangle, Kevin; Central Michigan University, Institute for Great Lakes } \\
\text { Research }\end{array}$ \\
\hline $\begin{array}{r}\text { Is the invited manuscript for } \\
\text { consideration in a Special } \\
\text { Issue? : }\end{array}$ & N/A \\
\hline Keyword: & $\begin{array}{l}\text { CLIMATE CHANGE < General, Great Lakes, fish, MIGRATION < General, } \\
\text { INVASIVE SPECIES < Organisms }\end{array}$ \\
\hline \multicolumn{2}{|c}{} \\
\hline
\end{tabular}

SCHOLARONE ${ }^{\text {m }}$

Manuscripts 
$8{ }^{1}$ Central Michigan University, Department of Biology, Mount Pleasant, MI, USA 48858.

9 mccan1e@cmich.edu, pangl1k@cmich.edu

$10 \quad{ }^{2}$ U.S. Geological Survey, Great Lakes Science Center, Hammond Bay Biological Station, 11188

11 Ray Road, Millersburg, MI, USA 49759.njohnson@usgs.gov

12

13 Key words: climate change; Great Lakes; fish; migration; invasive species 


\section{Abstract}

By investigating historic trapping records of invasive sea lamprey (Petromyzon marinus)

16 throughout tributaries to the Laurentian Great Lakes, we found that upstream spawning

17 migration timing was highly correlated with stream temperatures over large spatial and temporal

18 scales. Furthermore, several streams in our study exceeded a critical spring thermal threshold

19 (i.e., $15^{\circ} \mathrm{C}$ ) and experienced peak spawning migration up to 30 days earlier than the 1980 s,

20 whereas others were relatively unchanged. Streams exhibiting warming trends and earlier

21 migration were spatially clustered and generally found on the leeward side of the Great Lakes

22 where the lakes most affect local climate. These findings highlight that all streams are not

23 equally impacted by climate change and represent, to our knowledge, the first observation

24 linking long-term changes in stream temperatures to shifts in migration timing of an invasive

25 fish. Earlier sea lamprey migration in Great Lakes tributaries may improve young of the year

26 growth and survival, but not limit their spatial distribution, making sea lamprey control more

27 challenging. 


\section{Introduction}

Global climate change has had increasingly strong effects on environmental patterns during the past several decades (Dale et al. 2001; Vaughan et al. 2003; Chen et al. 2006). In aquatic systems, climate change is predicted to alter fish thermal habitat regimes (Magnuson et al. 1990; Magnuson et al. 1997; Ficke et al. 2007), growth rates and recruitment (Hill and Magnuson 1990; Pörtner et al. 2001), as well as migration and spawning timing (Holmes 1990; Isaak et al. 2012). Many of these predictions have since been validated. For example, shifts in thermal habitat regimes have been shown to occur for freshwater fishes in Wisconsin (Lyons et al. 2010) as well as pelagic (Murawski 1993) and benthic (Perry et al. 2005) marine fishes around the world. Additionally, historical otolith data show a change in growth rates of marine fish as a result of warming sea temperatures (Thresher et al. 2007). Increased sea surface temperatures in the Sargasso Sea have been shown to cause a decrease in primary productivity, indirectly decreasing glass eel (Anguilla spp.) recruitment (Bonhommeau et al. 2008). Changes in migration timing of salmonids due to warming streams have been documented in the Pacific Northwest (Quinn and Adams 1996; Quinn et al. 1997). These studies, among others, provide evidence that warming climates are affecting ecological and biological processes in aquatic systems, but we suggest that managers also need to consider how aquatic invasive species and their control are influenced by warming temperatures (Hellmann et al. 2008; Rahel and Olden 2008), including changes in migration timing.

Invasive sea lamprey (Petromyzon marinus) in the Laurentian Great Lakes is a useful species for evaluating the impact of warming streams on fish migration, because various stages of the sea lamprey life cycle have been shown to be highly temperature-dependent including egg development and larval growth (Holmes and Lin 1994), the timing of metamorphosis (Holmes et 
51 al. 1994), and the adult spawning migration (Binder et al. 2010). Due to their devastating effects

52 on the Great Lakes Fishery in the 1900s, the sea lamprey has been of particular interest in many

53 ecological studies (Christie and Goddard 2003; Hansen et al. 2016) including a long-term and

54 geographically broad data set describing sea lamprey spawning migrations (Mullett et al. 2003).

Here, we evaluated the long-term data set describing stream temperatures and sea

56 lamprey trap catches to determine which streams throughout the Great Lakes have warmed and if

57 sea lamprey migration timing has shifted in warming streams. We hypothesized that sea lamprey

58 migration timing is largely driven by stream temperature (Binder and McDonald 2008; Binder et

59 al. 2010), and as such, if stream temperatures have warmed earlier each spring, sea lamprey

60 migration timing would have shifted correspondingly. Specifically, three predictions were

61 evaluated as a test for our hypothesis: (1) sea lamprey migration timing would be highly

62 correlated with stream temperature, (2) streams throughout the Great Lakes Basin warmed earlier

63 each spring, and (3) in response to earlier stream warming, sea lamprey run timing also occurred

64 earlier each spring.

66 Methods

67 Data Set

The Great Lakes Fishery Commission, which organizes sea lamprey control in the Great

69 Lakes, provided access to the long-term data set describing adult sea lamprey trap catch (Mullett

70 et al. 2003). Sustained and systematic trapping efforts began in the 1970s and have occurred at

71 more than 118 trapping sites located throughout the Great Lakes Basin, primarily using portable

72 traps installed below dams, or dam-integrated traps. The data set includes the species and number

73 of individuals trapped at each site as well as water temperature on days that each trapping site 
74 was checked. Full details of the sampling methods are described in Mullett et al. (2003). For this

75 study, we assumed that trap catch mirrors migration timing, because the location and timing of

76 trap deployment is specifically targeting adults migrating upstream to spawn.

77 To ensure we were using the most complete and robust trapping data, we only included

78 streams with data from at least 30 years spanning from 1984 or earlier through 2014 or later. To

79 better ensure trapping efforts did not miss the migration peak, we excluded years that had the

80 highest sea lamprey catch on the first or last day the trap was checked. Additionally, the trap site

81 must have been checked a minimum of 5 times each year. The average number of trap checks per

82 site per season was 29.4 and the average trap deployment length was 44.9 days (Table 1), during

83 which the vast majority of adult sea lamprey were surveyed each year (Mullett et al. 2003).

84 Given these selection criteria, our subset included 29 streams total, 8 streams located in Canada 85 and 21 streams located in the United States (Table 1).

86 Analysis

87 For the analysis, we chose variables most relevant to sea lamprey biology. Previous studies found that sea lamprey migration peaks when stream temperatures reach approximately

$8915^{\circ} \mathrm{C}$ (Applegate 1950; Binder et al. 2010). Subsequently, we used the Julian day at which streams each year first reached $15^{\circ} \mathrm{C}\left(\mathrm{D}_{15^{\circ}} \mathrm{C}\right)$ to represent spring temperature conditions. Because

91 trap catches within a year were often not normally distributed, we used the Julian day when $50 \%$

92 of the total annual trap catch occurred $\left(\mathrm{D}_{50 \%}\right)$ to represent the timing of peak spawning migration 93 for a given year.

To test our first prediction that sea lamprey migration timing would be highly correlated 95 with stream temperature, we determined if $\mathrm{D}_{50 \%}$ was influenced by $\mathrm{D}_{15^{\circ} \mathrm{C}}$ using a general linear 
mixed model. In this case, we ran a single analysis using data from our 29 study streams with stream identity as a random effect.

To test our second prediction that streams throughout the Great Lakes Basin warmed earlier each spring, we determined if $\mathrm{D}_{15^{\circ} \mathrm{C}}$ decreased over our study period using a general linear model. To determine if streams differed in their changes over time, our model included stream identity and the interaction between stream identity and year as factors. To better evaluate changes in individual streams, we used a simple slope analysis to test whether temperature changes for a given stream differed significantly from zero. Using these slopes (i.e., mean annual change in $\mathrm{D}_{15^{\circ}} \mathrm{C}$ ) from each study stream, we ran a spatial autocorrelation analysis to determine whether geographic clustering existed among streams based on whether or not they experienced temperature shifts over time.

To test our third prediction that in response to earlier stream warming, sea lamprey run timing also occurred earlier each spring, we determined if $\mathrm{D}_{50 \%}$ decreased over our study period using a general linear model, which again included stream identity and the interaction between stream identity and year as factors. As with the second prediction, we used a simple slope analysis to evaluate shifts in sea lamprey migration timing for each stream and a spatial autocorrelation analysis to determine whether geographic clustering exists among streams based on whether or not they experienced shifts sea lamprey migration timing. To determine if a relationship exists between the magnitude of changes in $\mathrm{D}_{15^{\circ} \mathrm{C}}$ and $\mathrm{D}_{50 \%}$, we ran a final linear regression using magnitude of change in $\mathrm{D}_{15^{\circ} \mathrm{C}}$ as the independent variable and magnitude of change in $\mathrm{D}_{50 \%}$ as the dependent variable.

All analyses were performed in R (3.2.3). We ran spatial autocorrelation analyses using the Moran.I function within the APE (4.0) R package (Paradis et al. 2004). Figures were created 
119

120

121

122

123

124

125

126

127

128

129

130

131

132

133

134

135

136

137

138

139

140

141

with the ggplot2 (2.2.1) R package (Wickham 2009) with the exception of the maps, which were created using arcMap.

\section{Results}

Prediction 1 was supported; sea lamprey migration timing was highly correlated with stream temperature across streams. When streams reached $15^{\circ} \mathrm{C}$ earlier in the year, the timing of when $50 \%$ of the sea lamprey migrated tended to occur earlier in the year, and vice versa $\left(F_{1,875}\right.$ $=467.11, p<0.01)$. The relationship was consistent across the latitudinal gradient of the entire Great Lakes Basin, with $\mathrm{D}_{15^{\circ} \mathrm{C}}$ explaining $61 \%$ of the overall variance in $\mathrm{D}_{50 \%}$ (Figure 1). Prediction 2 was partially supported; we found stream warming to be variable both over time and across streams (stream-by-year interaction: $F_{29,875}=50.76, p<0.01$ ). While the majority of streams in our analysis trended toward earlier spring warming, some had no change, and one stream even warmed significantly later in the year (Figure 2a; plots for individual streams are provided in Figure S1). Additionally, streams with similar warming trends were clustered spatially in several areas throughout the Great Lakes Basin (Moran's $I=0.20, p=0.01$; Figure 2a). Most streams exhibiting earlier warming were located on the leeward (eastern) side of the Great Lakes (Figure 2a).

Prediction 3 was partially supported; as with $\mathrm{D}_{15^{\circ} \mathrm{C}}$, changes in $\mathrm{D}_{50 \%}$ over time differed among streams (stream-by-year interaction: $F_{28,847}=2.61, p<0.01$; Figure $2 \mathrm{~b}$; plots for individual streams are provided in Figure S2). Observed changes in $\mathrm{D}_{50 \%}$ were further related to those of $\mathrm{D}_{15^{\circ} \mathrm{C}}$, such that streams that experienced earlier warming were more likely to experience $50 \%$ migration earlier as well $\left(R^{2}=0.59, F_{1,27}=39.29, p<0.01\right.$; Figure 3$)$. In fact, the one stream that experienced significantly later warming also experienced later dates of $50 \%$ 
142 migration. Further, streams where sea lamprey were migrating earlier in the year were spatially

143 clustered (Moran's $I=0.30, p<0.01$; Figure $2 b$ ) and located on the leeward (eastern) side of the

144 Great Lakes, similar to that observed for $\mathrm{D}_{15^{\circ} \mathrm{C}}$.

145

146

147

148

149

150

151

152

153

154

155

156

157

158

159

160

161

162

163

164

\section{Discussion}

Our study revealed a strong relationship between spring stream temperatures and sea lamprey migration timing across the Great Lakes Basin over the last several decades. We found that the sea lamprey spawning migration tended to occur earlier in streams that reached $15^{\circ} \mathrm{C}$ earlier in the year compared to those that reached $15^{\circ} \mathrm{C}$ later in the year. These findings are consistent with previous studies that have shown the general influence of temperature on locomotor activity (Binder and McDonald 2008) and the specific temperature at which peak migration occurs (Applegate 1950; Binder et al. 2010). Here we show how these effects of temperature act in a consistent fashion over the large spatial extent of the Great Lakes Basin. While our analysis showed a strong correlation between stream temperature and sea lamprey migration timing, some variability in migration timing was left unexplained, suggesting that our surrogate of run timing (trap catch) had inherent sampling variability or that environmental factors in addition to river temperature influence run timing. For example, Binder et al. (2010) found that the rate at which temperature rise in the spring can also affect migration timing. Future analyses, particularly those that are building predictive models of migration timing, should consider the speed of spring warming and other variables (e.g., photoperiod, lunar cycles, lake temperature, larval pheromone). Additionally, warmer temperatures could increase larval productivity in some streams, and because adult sea lamprey use chemical cues released by larvae to locate streams with suitable spawning habitat (Vrieze and Sorensen 2001; Meckley et 
165 166 167 168 169 170 171 172 173 174 175 176 177 178 179 180 181 182 183 184 185 186

al. 2014), increased larval productivity could influence migration timing. However, the influence of pheromones and other factors on migration timing is likely to be much less than temperature given the findings of other studies (Applegate 1950; Wagner et al. 2009; Meckley et al. 2014).

The direction and magnitude of change in both water temperature and sea lamprey migration timing was variable among our study streams. How global climate change is expected to influence a stream depends on several factors, including local climate, hydrology, and geomorphology (Milly et al. 2005; Nelson et al. 2009). While our study was not designed to identify the underlying drivers of stream temperature changes, the nature of the spatial clustering we observed suggests a regional factor, such as local climate, is important. The location of these clusters in relation to the Great Lakes may also be informative. We found streams exhibiting warming trends and earlier migration were generally found on the leeward (eastern) side of the Great Lakes. Interestingly, regional climate models of the Great Lakes Basin (e.g., Gula and Peltier 2012; Xue et al. 2017) in combination with long-term field observations (e.g., Mason et al. 2016) have identified differences in climate change between windward and leeward sides of the lakes, resulting from feedbacks between the lakes and the atmosphere. These differences are particularly large for snowfall and snowpack (Gula and Peltier 2012, Demaria et al. 2016), which are relevant variables to our study because they directly impact the spring warming of streams (Smith and Lavis 1975, Kobayashi 1985). The role that snow and other Great Lakes-influenced climate variables play in our observed spatial clusters, while outside the scope of this study, is an intriguing question that warrants further investigation as it may be broadly informative to how stream ecosystems around large lakes will be affected by climate change.

The relatively broad range of magnitudes of change in sea lamprey migration timing demonstrates the complexity of how streams are influenced by the effects of climate change. 
188 Previous studies on migration timing of migratory fishes also showed a wide range in

189 magnitudes of change (Quinn and Adams 1996; Quinn et al. 1997; Robards and Quinn 2002;

190 Juanes et al. 2004); however, their small number of study streams across a relatively smaller

191 geographic area caused, in many instances, conflicting results among studies. Our more inclusive

192 study allowed us to better capture the wide range of variability in migration shifts experienced by

193 streams, therefore our results show consistencies with many previous studies that may have

194 conflicting results compared to one another. For example, American shad (Alosa sapidissima) in

195 the Columbia River Basin and Atlantic salmon (Salmo salar) in northern New England were

196 found to have relatively large shifts to earlier migration, ranging from -0.4 to -0.9 days per year

197 over several decades (Quinn and Adams 1996; Juanes et al. 2004). In comparison, we found six

198 streams where sea lamprey migration timing was earlier than -0.4 days per year. Additionally,

199 Sockeye salmon (Oncorhynchus nerka) in the Columbia River Basin had relatively small shifts

200 to earlier migration, ranging from -0.13 to -0.23 days per year over several decades (Quinn and

201 Adams 1996; Quinn et al. 1997). In comparison, we found eight streams with earlier sea lamprey

202 migration ranging from -0.1 to -0.3 days per year. Finally, steelhead (Oncorhynchus mykiss) at a

203 location in the Columbia River Basin were actually found to migrate up to 21 days later ( 0.44

204 days per year) over several decades (Robards and Quinn 2002), which again is consistent with

205 our results as we found six streams with later sea lamprey migration ranging from 0.14 to 0.64

206 days per year. The observed discrepancies in migration shifts between sea lamprey in the Great

207 Lakes Basin, sockeye salmon (Quinn and Adams 1996), and Atlantic salmon (Juanes et al. 2004)

208 again highlight the idea that local climates may be an important factor in determining a stream's

209 sensitivity to larger-scale global climate change. These discrepancies are likely also influenced

210 by differences in species life history. For instance, Quinn and Adams (1996) suggest that 
211 differences in migration shifts of sockeye salmon and American shad in the Columbia River

212 Basin may actually be driven by differences in their natural histories. Shad spawn shortly after

213 they enter rivers, so their larvae experience very similar stream conditions as the spawning

214 adults, which could have driven the evolution of greater behavioral plasticity to changing

215 environments (Quinn and Adams 1996). Sea lamprey also spawn shortly after they enter rivers

216 (Applegate 1950), suggesting their life history may be important to their sensitivity to changes in

217 stream temperature.

A shift in migration timing for Great Lakes sea lamprey populations could make

219 controlling this species and protecting the 7 billion dollar-a-year fishery even more difficult.

220 Earlier spawning means earlier egg hatching, giving larval sea lamprey a longer period of time to

221 develop and grow prior to their first winter, especially in northern latitude streams such as the St.

222 Marys River. This change could not only potentially increase a stream's production of

223 metamorphosing sea lamprey, but metamorphosis could occur a year sooner than historically

224 observed. Typically 3-6 years is required for sea lamprey larvae in the Great Lakes to

225 metamorphose to the parasitic stage (Beamish and Potter 1975; Quintella et al. 2003). As a

226 result, chemical treatments to control larval sea lamprey populations may need to occur a year

227 sooner in those streams that are more sensitive to warming as the effects of climate change

228 continue. Furthermore, metamorphosed sea lamprey that survive the sea lamprey control

229 program will likely cause more damage to the fishery under climate warming scenarios. For

230 example, Cline et al. (2014) correlated the warming of the Great Lakes with increased parasitic

231 sea lamprey growth rates. Larger parasitic sea lamprey are likely to have a much greater impact

232 on fish populations throughout the lakes, but may not experience higher natural mortality rates

233 like other fast growing fishes (grow fast and die young; Pauly 1980), because the duration of the 
234 parasitic life stage, when most growth occurs, is fixed between 12 to 18 months and adult sea

235 lamprey die after spawning (Applegate 1950). Under current warming trends, we do not expect many Great Lakes tributaries would become too warm to support sea lamprey given that they can

237 tolerate temperatures up to $30^{\circ} \mathrm{C}$ (Potter 1980), and in their native range, sea lamprey occupy 238 streams as far south as Florida in North America and southern Spain in Europe (Hansen et al. 239 2016).

Given the large spatial and temporal scale of this study, some aspects of the design were not ideal, but do not necessarily discount the observation of warming streams and earlier run timing of sea lamprey. A possible deficiency was that sea lamprey control actively applies selective lampricides to Great Lakes tributaries to kill larval sea lamprey, including the streams

244 where adult sea lamprey are trapped (Christie and Goddard 2003). Lampricide application could have two consequences for our analysis. First, adult sea lamprey populations may have declined

246 through our time series and low abundance adult sea lamprey populations may have different 247 migration phenologies. However, we think this scenario is unlikely because although sea 248 lamprey populations are 90\% lower than historic highs, major declines in population occurred 249 during the 1960s; adult sea lamprey populations have been relatively stable through our time 250 series (Sullivan et al. 2015). Second, lampricide treatment will kill adult sea lamprey if applied 251 during the spawning migration. While lampricide treatment could have occurred on some of our 252 study streams during some years, applications generally occur once every four years during the 253 summer and fall, which would be after the trapping period. Also, our data inclusion criteria 254 would have prevented us from using data from years when trap catch was very low. A deficiency 255 of our spatial analysis was that some geographic regions of the Great Lakes have not been 256 consistently trapped due to their remoteness or lack of suitable tributaries for trapping. These 
257 areas include as northern Lake Superior, western Lake Michigan, and eastern Lake Huron.

258 Additional trapping data from all areas of the Great Lakes, especially additional windward

259 locations in the upper Great Lakes, would have further strengthened evidence of spatial

260 clustering.

In the Great Lakes, as stream and lake temperatures increase due to the effects of

262 predicted climate change, fish production is predicted to increase due to improvements in 263 temperature dependent biological processes such as egg development, larval growth rates, and 264 metabolic rates (Hill and Magnuson 1990; Holmes and Youson 1997; Magnuson et al. 1997).

265 Increased production of valued fishes would be beneficial to economies worldwide, but 266 increased production of invasive species could negate these gains. Shifts in migration and 267 reproduction timing may have large implications for the control and viability of invasive and 268 valued fish populations worldwide (Rahel et al. 2008). Natural resource managers and policy 269 makers may better protect aquatic resources by considering changes in aquatic communities over

270 large geographic and temporal scales to determine whether fishes, either invasive or valued, have 271 been showing changes in reproduction timing.

\section{Acknowledgement}

$274 \quad$ Financial support for this project was provided by Central Michigan University,

275 Michigan Sea Grant, and the Great Lakes Fishery Commission. Historical sea lamprey trapping

276 records were provided by the Great Lakes Fishery Commission, U.S. Fish and Wildlife Service,

277 and Fisheries and Oceans Canada. Dr. Thomas Binder, Gale Bravener, and Peter Hrodey

278 provided constructive review comments, aiding in the improvement of the manuscript. Dr. Daria

279 Kluver provided helpful comments regarding climate modeling in the Great Lakes. Any use of 
280 trade, product, or firm names is for descriptive purposes only and does not imply endorsement by

281 the U.S. Government.

282

\section{References}

284 Applegate, V.C. 1950. Natural history of the sea lamprey, Petromyzon marinus, in Michigan 285 (Doctoral dissertation, University of Michigan).

286

287

288

289

290

291

292

293

294

295

296

297

298

299

300

301

302
Beamish, F.W.H., and Potter, I.C. 1975. The biology of the anadromous Sea lamprey (Petromyzon marinus) in New Brunswick. Journal of Zoology, 177(1):57-72.

Binder, T.R., and McDonald, D.G. 2008. The role of temperature in controlling diel activity in upstream migrant sea lampreys (Petromyzon marinus). Canadian Journal of Fisheries and Aquatic Sciences, 65(6):1113-1121.

Binder, T.R., McLaughlin, R.L., and McDonald, D.G. 2010. Relative importance of water temperature, water level, and lunar cycle to migratory activity in spawning-phase sea lampreys in Lake Ontario. Transactions of the American Fisheries Society, 139(3):700712.

Bonhommeau, S., Chassot, E., Planque, B., Rivot, E., Knap, A.H., and Le Pape, O. 2008. Impact of climate on eel populations of the Northern Hemisphere. Marine Ecology Progress Series, 373:71-80.

Chen, J.L., Wilson, C.R., and Tapley, B.D. 2006. Satellite gravity measurements confirm accelerated melting of Greenland ice sheet. Science, 313(5795):1958-1960.

Christie, G.C., and Goddard, C.I. 2003. Sea Lamprey International Symposium (SLIS II): advances in the integrated management of sea lamprey in the Great Lakes. Journal of Great Lakes Research, 29:1-14. 
303

304

305

306

307

308

309

310

Cline, T.J., Kitchell, J.F., Bennington, V., McKinley, G.A., Moody, E.K., and Weidel, B.C. 2014. Climate impacts on landlocked sea lamprey: Implications for host-parasite interactions and invasive species management. Ecosphere, 5(6):1-13.

Dale, V.H., Joyce, L.A., McNulty, S., Neilson, R.P., Ayres, M.P., Flannigan, M.D., Hanson, P.J., Irland, L.C., Lugo, A.E., Peterson, C.J., and Simberloff, D. 2001. Climate change and forest disturbances climate change can affect forests by altering the frequency, intensity, duration, and timing of fire, drought, introduced species, insect and pathogen outbreaks, hurricanes, windstorms, ice storms, or landslides. BioScience, 51(9):723-734.

Demaria, E.M.C., Roundy, J.K., Wi, S., and Palmer, R.N. 2016. The effects of climate change on seasonal snowpack and the hydrology of the Northeastern and upper Midwest United States. Journal of Climate, 29:6527-6541.

Ficke, A.D., Myrick, C.A., and Hansen, L.J. 2007. Potential impacts of global climate change on freshwater fisheries. Reviews in Fish Biology and Fisheries, 17(4):581-613.

Gula, J., and Peltier, W.R. 2012. Dynamical downscaling over the Great Lakes Basin of North America using the WRF regional climate model: the impact of the Great Lakes system on regional greenhouse warming. Journal of Climate, 25(21):7723-7742.

Hansen, M.J., Madenjian, C.P., Slade, J.W., Steeves, T.B., Almeida, P.R., and Quintella, B.R. 2016. Population ecology of the sea lamprey (Petromyzon marinus) as an invasive species in the Laurentian Great Lakes and an imperiled species in Europe. Review of Fish Biology and Fisheries, 26:509-535.

Hellmann, J.J., Byers, J.E., Bierwagen, B.G., and Dukes, J.S. 2008. Five potential consequences of climate change for invasive species. Conservation Biology, 22(3):534-543. 
325

326

327

328

329

330

331

332

333

334

335

336

337

338

339

340

341

342

343

344

345

346

Hill, D.K., and Magnuson, J.J. 1990. Potential effects of global climate warming on the growth and prey consumption of Great Lakes fish. Transactions of the American Fisheries Society, 119(2):265-275.

Holmes, J.A. 1990. Sea lamprey as an early responder to climate change in the Great Lakes Basin. Transactions of the American Fisheries Society, 119(2):292-300.

Holmes, J.A., Beamish, F.W., Seelye, J.G., Sower, S.A., and Youson, J.H. 1994. Long-term influence of water temperature, photoperiod, and food deprivation on metamorphosis of sea lamprey, Petromyzon marinus. Canadian Journal of Fisheries and Aquatic Sciences, 51(9):2045-2051.

Holmes, J.A., and Lin, P. 1994. Thermal niche of larval sea lamprey, Petromyzon marinus. Canadian Journal of Fisheries and Aquatic Sciences, 51(2):253-262.

Holmes, J.A., and Youson, J.H. 1997. Laboratory study of the effects of spring warming and larval density on the metamorphosis of sea lampreys. Transactions of the American fisheries Society, 126(4):647-657.

Isaak, D.J., Wollrab, S., Horan, D., and Chandler, G. 2012. Climate change effects on stream and river temperatures across the northwest US from 1980-2009 and implications for salmonid fishes. Climatic Change, 113(2):499-524.

Juanes, F., Gephard, S., and Beland, K.F. 2004. Long-term changes in migration timing of adult Atlantic salmon (Salmo salar) at the southern edge of the species distribution. Canadian Journal of Fisheries and Aquatic Sciences, 61(12):2392-2400.

Kobayashi, D. 1985. Separation of the snowmelt hydrograph by stream temperatures. Journal of Hydrology, 76(1-2):155-162. 
347 348 349 350 351 352 353 354 355 356 357 358 359 360 361 362 363 364 365 366 367 368

Lyons, J., Stewart, J.S., and Mitro, M. 2010. Predicted effects of climate warming on the distribution of 50 stream fishes in Wisconsin, USA. Journal of Fish Biology, 77(8):18671898.

Magnuson, J.J., Meisner, J.D., and Hill, D.K. 1990. Potential changes in the thermal habitat of Great Lakes fish after global climate warming. Transactions of the American Fisheries Society, 119(2):254-264.

Magnuson, J.J., Webster, K.E., Assel, R.A., Bowser, C.J., Dillon, P.J., Eaton, J.G., Evans, H.E., Fee, E.J., Hall, R.I., Mortsch, L.R., and Schindler, D.W. 1997. Potential effects of climate changes on aquatic systems: Laurentian Great Lakes and Precambrian Shield Region. Hydrological processes, 11(8):825-871.

Mason, L.A., Riseng, C.M., Gronewold, A.D., Rutherford, E.S., Wang, J., Clites, A., Smith, S.D.P., and McIntyre, P.B. 2016. Fine-scale spatial variation in ice cover and surface temperature trends across the surface of the Laurentian Great Lakes. Climate Change, 138:71-83.

Meckley, T.D., Wagner, C.M., and Gurarie, E. 2014. Coastal movements of migrating sea lamprey (Petromyzon marinus) in response to a partial pheromone added to river water: implications for management of invasive populations. Canadian Journal of Fisheries and Aquatic Sciences, 71(4):533-544.

Milly, P.C.D., Dunne, K.A., and Vecchia, A.V. 2005. Global pattern of trends in streamflow and water availability in a changing climate. Nature, 438:347-350.

Mullett, K.M., Heinrich, J.W., Adams, J.V., Young, R.J., Henson, M.P., McDonald, R.B., and Fodale, M.F. 2003. Estimating lake-wide abundance of spawning-phase sea lampreys 
(Petromyzon marinus) in the Great Lakes: extrapolating from sampled streams using regression models. Journal of Great Lakes Research, 29:240-252.

Murawski, S.A. 1993. Climate change and marine fish distributions: forecasting from historical analogy. Transactions of the American Fisheries Society, 122(5):647-658.

Nelson, K.C., Palmer, M.A., Pizzuto, J.E., Moglen, G.E., Angermeier, P.L., Hilderbrand, R.H., Dettinger, M., and Hayhoe, K. 2009. Forecasting the combined effects of urbanization and climate change on stream ecosystems: from impacts to management options. Journal of Applied Ecology, 46:154-163.

Paradis, E., Claude, J., and Strimmer, K. 2004. APE 4.0: Analyses of phylogenetics and evolution in R language. Bioinformatics, 20:289-290.

Pauly, D. 1980. On the interrelationships between natural mortality, growth parameters, and mean environmental temperature in 175 fish stocks. Journal du Conseil, 39(2):175-192.

Perry, A.L., Low, P.J., Ellis, J.R., and Reynolds, J.D. 2005. Climate change and distribution shifts in marine fishes. Science, 308(5730):1912-1915.

Pörtner, H.O., Berdal, B., Blust, R., Brix, O., Colosimo, A., De Wachter, B., Giuliani, A., Johansen, T., Fischer, T., Knust, R., and Lannig, G. 2001. Climate induced temperature effects on growth performance, fecundity and recruitment in marine fish: developing a hypothesis for cause and effect relationships in Atlantic cod (Gadus morhua) and common eelpout (Zoarces viviparus). Continental Shelf Research, 21(18):1975-1997.

Potter, I.C. 1980. Ecology of larval and metamorphosing lampreys. Canadian Journal of Fisheries and Aquatic Sciences, 37(11):1641-1657.

Quinn, T.P., and Adams, D.J. 1996. Environmental changes affecting the migratory timing of American shad and sockeye salmon. Ecology, 77(4):1151-1162. 
392 Quinn, T.P., Hodgson, S., and Peven, C. 1997. Temperature, flow, and the migration of adult 393 sockeye salmon (Oncorhynchus nerka) in the Columbia River. Canadian Journal of Fisheries and Aquatic Sciences, 54(6):1349-1360.

Quintella, B.R., Andrade, N.O., and Almeida, P.R. 2003. Distribution, larval stage duration and growth of the sea lamprey ammocoetes, Petromyzon marinus L., in a highly modified river basin. Ecology of Freshwater Fish, 12(4):286-293.

R Core Team, 2015. R: A language and environment for statistical computing. R Foundation for Statistical Computing, Vienna, Austria. URL https://www.R-project.org/.

400

401

402

403

404

405

406

407

408

409

410
Rahel, F.J., and Olden, J.D. 2008. Assessing the effects of climate change on aquatic invasive species. Conservation Biology, 22(3):521-533.

Rahel, F.J., Bierwagen, B., and Taniguchi, Y. 2008. Managing aquatic species of conservation concern in the face of climate change and invasive species. Conservation Biology, 22(3):551-561.

Robards, M.D., and Quinn, T.P. 2002. The migratory timing of adult summer-run steelhead in the Columbia River over six decades of environmental change. Transactions of the American Fisheries Society, 131(3):523-536.

Smith, K., and Lavis, M.E. 1975. Environmental influences on the temperature of a small upland stream. Oikos, 26:228-236.

Sullivan, P., Adair, R., and Woldt, A. 2015. Sea lamprey Control in the Great Lakes 2015. Annual Report to the Great Lakes Fishery Commission. Ann Arbor, MI, 2016.

Thresher, R.E., Koslow, J.A., Morison, A.K., and Smith, D.C. 2007. Depth-mediated reversal of the effects of climate change on long-term growth rates of exploited marine fish. Proceedings of the National Academy of Sciences, 104(18):7461-7465.

19 of 25 
415 Vaughan, D.G., Marshall, G.J., Connolley, W.M., Parkinson, C., Mulvaney, R., Hodgson, D.A., 416 King, J.C., Pudsey, C.J., and Turner, J. 2003. Recent rapid regional climate warming on the Antarctic Peninsula. Climatic Change, 60(3):243-274.

418 Vrieze, L.A., and Sorensen, P.W. 2001. Laboratory assessment of the role of a larval pheromone 419 and natural stream odor in spawning stream localization by migratory sea lamprey (Petromyzon marinus). Canadian Journal of Fisheries and Aquatic Sciences, 58(12):2374-2385.

422 Wagner, C.M., Twohey, M.B., and Fine, J.M. 2009. Conspecific cueing in sea lamprey: do 423 reproductive migrations consistently follow the most intense larval odour? Animal Behavior, 78:593-599.

425 Wickham, H. 2009. Ggplot2: Elegant Graphics for Data Analysis. Springer-Verlag New York. 426 Xue, P., J.S. Pal, S. Ye, J.D. Lenters, C. Huang, and P.Y. Chu, 2017. Improving the Simulation 427 of Large Lakes in Regional Climate Modeling: Two-Way Lake-Atmosphere Coupling 428 with a 3D Hydrodynamic Model of the Great Lakes. Journal of Climate, 30(5):16051627. 
430 Table 1. For the 29 streams used in our analyses, this table shows the associated lake and

431 country, the total number of sea lamprey catch data entries, the range of years trapped, the total

432 number of years trapped, and the average number of days the traps were set per year.

\begin{tabular}{|c|c|c|c|c|c|}
\hline Tributary & Lake, Country & $\begin{array}{l}\text { Total number } \\
\text { of data entries }\end{array}$ & $\begin{array}{l}\text { Range of years } \\
\text { trapped }\end{array}$ & $\begin{array}{l}\text { Number of } \\
\text { years trapped } \\
\text { within range }\end{array}$ & $\begin{array}{c}\text { Average trap } \\
\text { deployment } \\
\text { (days) }\end{array}$ \\
\hline Betsie River & Michigan, US & 1099 & $1978-2015$ & 37 & 56.2 \\
\hline Betsy River & Superior, US & 684 & $1977-2015$ & 38 & 43.9 \\
\hline Boardman River & Michigan, US & 882 & $1978-2015$ & 37 & 49.3 \\
\hline Bowmanville Creek & Ontario, CA & 915 & $1981-2015$ & 35 & 43.9 \\
\hline Carp Lake River & Michigan, US & 961 & $1979-2015$ & 36 & 48.2 \\
\hline Carp River & Superior, CA & 588 & $1975-2014$ & 33 & 40.2 \\
\hline Cattaraugus Creek & Erie, US & 914 & $1980-2015$ & 36 & 33.9 \\
\hline Cheboygan River & Huron, US & 1624 & $1977-2015$ & 39 & 52.2 \\
\hline Duffins Creek & Ontario, CA & 1019 & $1981-2015$ & 35 & 52.9 \\
\hline Echo River & Huron, CA & 979 & $1980-2015$ & 31 & 52 \\
\hline Graham Creek & Ontario, CA & 751 & $1981-2014$ & 31 & 52.4 \\
\hline Grand River & Erie, US & 396 & $1978-2015$ & 33 & 24 \\
\hline Grindstone Creek & Ontario, US & 488 & $1978-2014$ & 34 & 37.2 \\
\hline Humber River & Ontario, CA & 2059 & $1981-2015$ & 35 & 60.8 \\
\hline Jordan River & Michigan, US & 951 & $1978-2014$ & 36 & 52.4 \\
\hline Little Salmon River & Ontario, US & 425 & $1978-2014$ & 35 & 31.9 \\
\hline Manistique River & Michigan, US & 1301 & $1977-2015$ & 39 & 44.4 \\
\hline Menominee River & Michigan, US & 771 & $1977-2014$ & 38 & 41.7 \\
\hline Middle River & Superior, US & 464 & $1984-2015$ & 32 & 33.1 \\
\hline Miners River & Superior, US & 349 & $1979-2014$ & 36 & 27.4 \\
\hline Ocqueoc River & Huron, US & 1361 & $1981-2015$ & 35 & 54.5 \\
\hline Peshtigo River & Michigan, US & 1066 & $1977-2015$ & 39 & 46.7 \\
\hline Rock River & Superior, US & 1552 & $1975-2015$ & 41 & 59.7 \\
\hline St Joseph River & Michigan, US & 805 & $1978-2015$ & 37 & 42.4 \\
\hline St Marys River & Huron, US & 1332 & $1977-2015$ & 39 & 46.1 \\
\hline Sterling Creek & Ontario, US & 919 & $1980-2015$ & 36 & 43.3 \\
\hline Stokely Creek & Superior, CA & 250 & $1981-2014$ & 30 & 27.1 \\
\hline Tahquamenon River & Superior, US & 1081 & $1977-2015$ & 39 & 47.7 \\
\hline Thessalon River & Huron, CA & 2194 & $1980-2015$ & 36 & 56.6 \\
\hline
\end{tabular}




\section{Figure Captions}

435 Figure 1. The relationship between the Julian day on which stream temperature first reached $43615^{\circ} \mathrm{C}\left(\mathrm{D}_{15^{\circ} \mathrm{C}}\right)$ and the Julian day on which $50 \%$ trap catch occurred $\left(\mathrm{D}_{50 \%}\right)$; the solid line 437 represents a regression line of the linear relationship.

439 Figure 2. Maps showing the 29 trap locations used in our analyses. Colors indicate slopes of

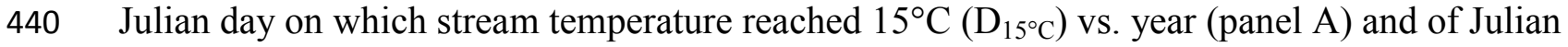
441 day on which 50\% trap catch occurred $\left(\mathrm{D}_{50 \%}\right)$ vs. year (panel B). Map source: Great Lakes 442 Information Network (GLIN).

443

444 Figure 3. The relationship between the magnitude of change in Julian day on which stream 445 temperature reached $15^{\circ} \mathrm{C}\left(\mathrm{D}_{15^{\circ}} \mathrm{C}\right)$ and the magnitude of change in Julian day on which $50 \%$ trap 446 catch occurred $\left(\mathrm{D}_{50 \%}\right)$ for each of our 29 streams; the solid line represents a regression line of the 447 linear relationship. 


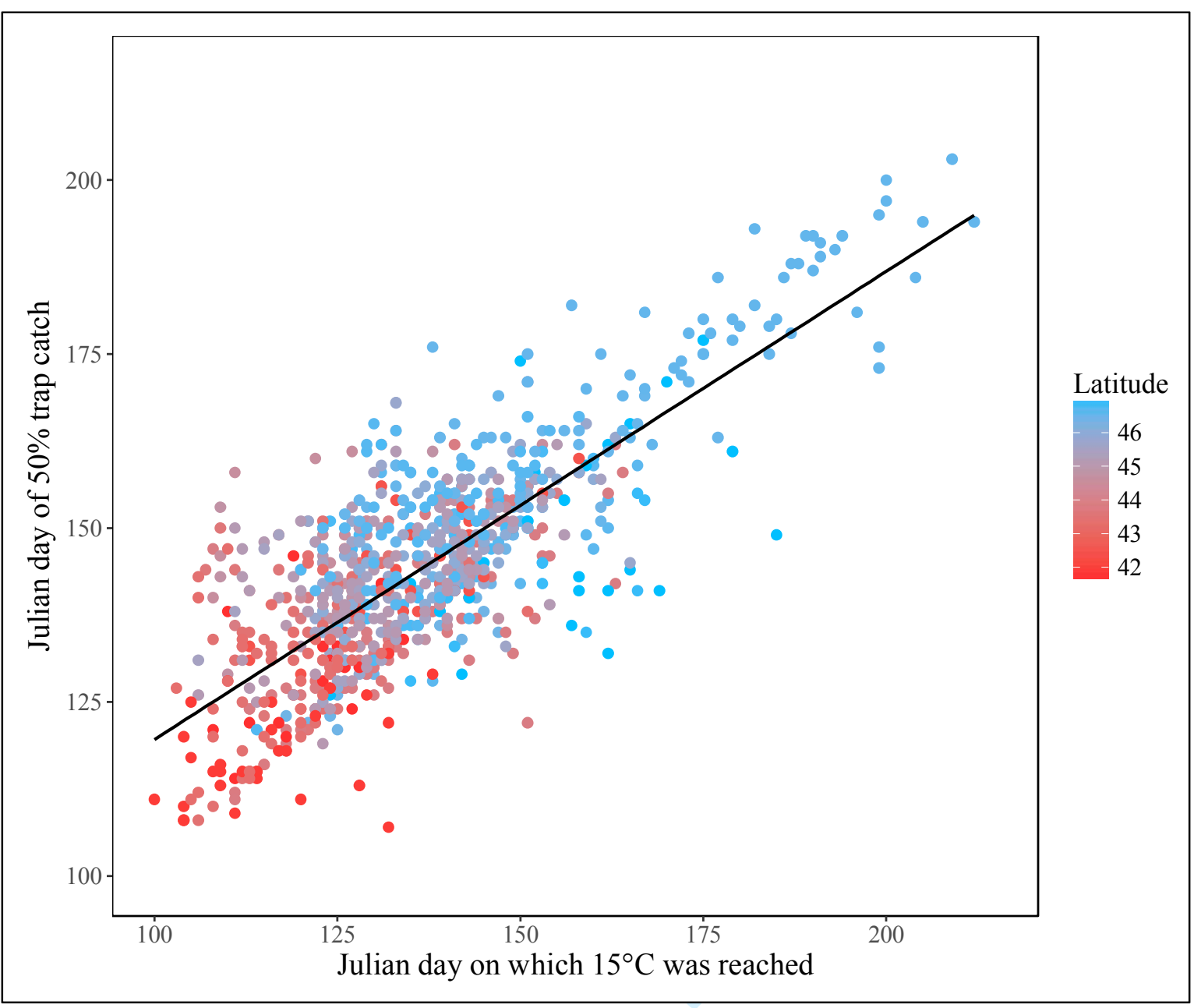

448

Figure 1 


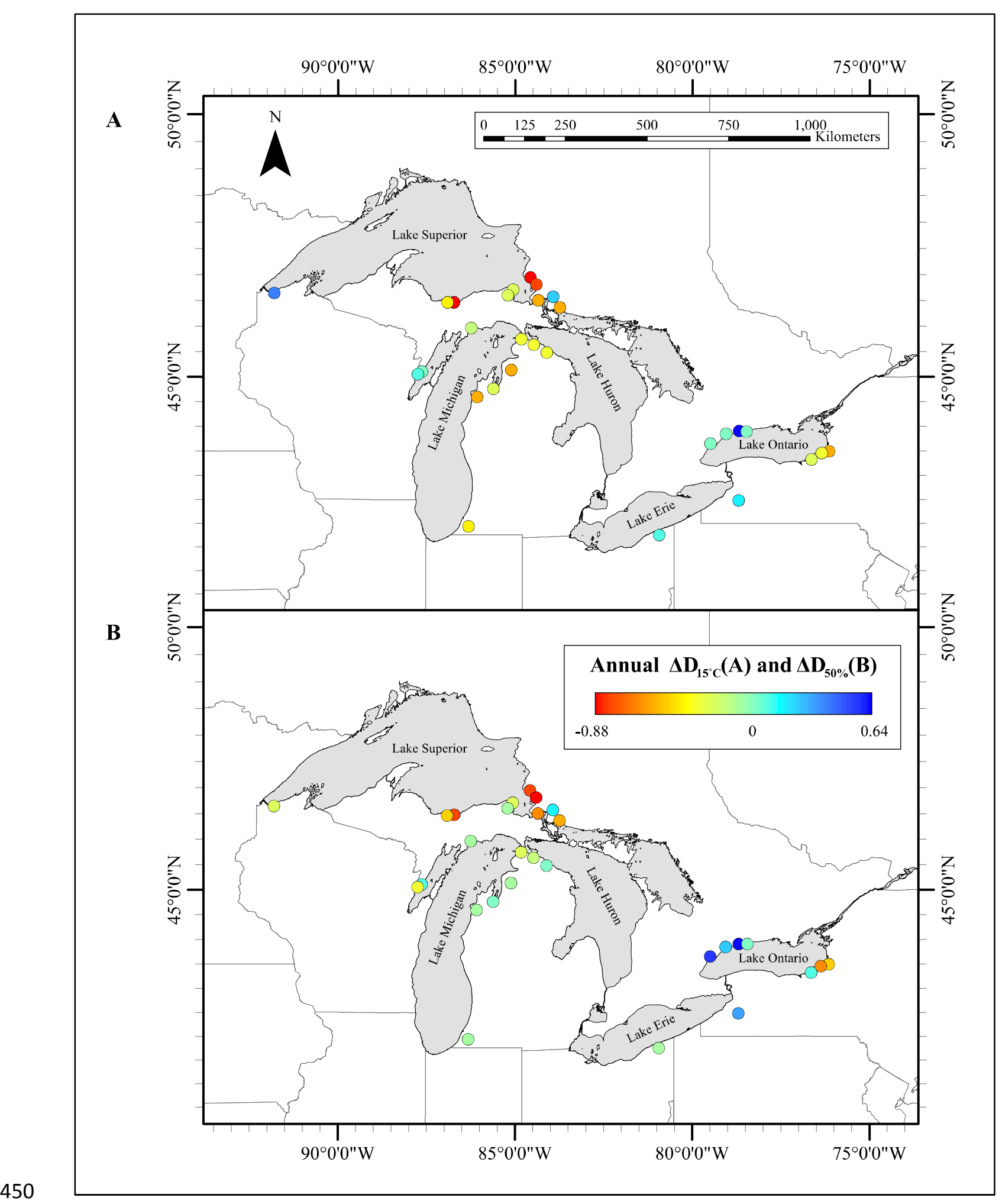

Figure 2 


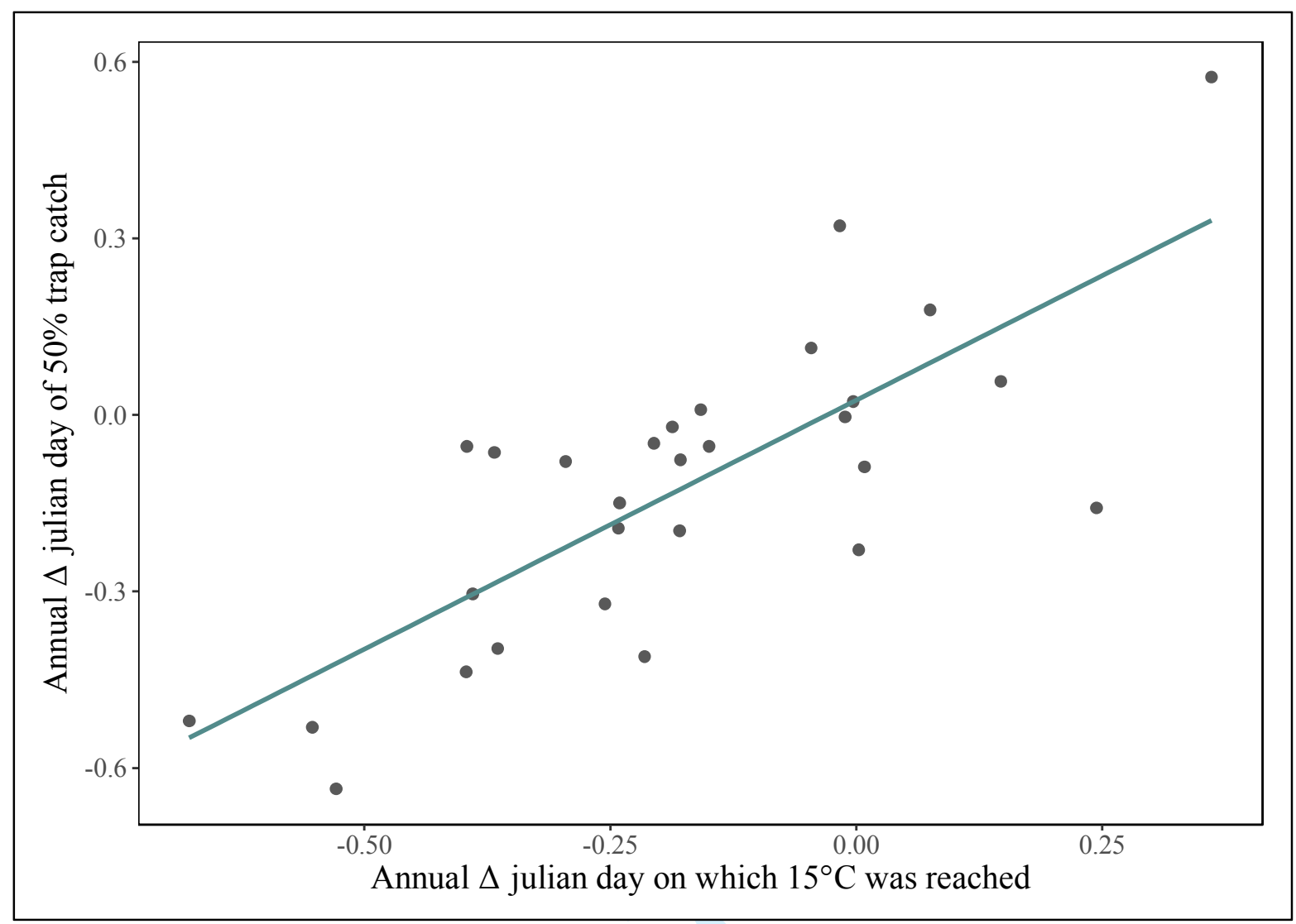

$453 \quad$ Figure 3 